\title{
Epicellular and nodular coccidiosis in the intestine of barbel Barbus barbus
}

\author{
Ferenc Baska* \\ Veterinary Medical Research Institute, Hungarian Academy of Sciences, PO Box 18, H-1581 Budapest, Hungary
}

\begin{abstract}
During parasitological examination of Danubian barbels, an epicellular and a nodular coccidiosis were demonstrated in the gut of mature fish specimens. Both coccidioses appeared in late spring as concurrent infections. In that period, the prevalence of the epicellular species was $18.4 \%$ while nodular coccidiosis was detected in 1 fish specimen only. The mucus drawn off from the gut mucosa contained unsporulated oocysts of a Goussia species developing in epicellular location. Based upon their morphological characteristics after sporulation, they were described as a new species by the name of Goussia koertingi. The gamogonic stages and unsporulated oocysts of the other unidentified species with supranuclear development were detected from nodules located in specific areas of the gut epithelium.
\end{abstract}

KEY WORDS: New species - Epicellular coccidiosis - Nodular coccidiosis - Barbel - Seasonal appearance $\cdot$ Histopathology

\section{INTRODUCTION}

Data on coccidial infections of Barbus species are relatively scarce in the literature. Shulman (1984) reported the occurrence of the common carp and crucian carp parasite Goussia carpelli in Barbus barbus; Alvarez-Pellitero \& Gonzalez-Lanza (1986a, b) described infection of the gut epithelium by Goussia carpelli in Barbus barbus bocagei as well as by Eimeria leucisci parasitic in the renal passages. In the water system of the River Danube, the helminthic fauna of the barbel has been studied most intensively (Zitnan $1965,1968)$. With respect to protozoan parasites of Danubian barbel, Reichenbach-Klinke (1962) mentioned the occurrence of some parasites belonging to Ciliata and Myxosporea, while Molnár (1966) reported on the pathologic effect of a gut-parasitic flagellate, determined then as Spironucleus elegans.

More information is available on protozoans parasitic in fish living in the Tisza, a tributary of the River Danube. Ergens et al. (1975) recorded 46 different protozoan species belonging to 10 families; however,

•E-mail: fero@novell.vmri.hu coccidia were detected only in Gobio spp. and in Chondrostoma nasus.

The frequent occurrence of epicellular and nodular coccidia of seasonal developmental cycle in the intestine of cyprinids has been known only since the studies of Molnár (1989). In addition to describing the new species Goussia balatonica and G. pannonica, he reported coccidia causing infections of this type (epicellular and nodular coccidiosis), referred to as Goussia spp., from several cyprinids.

The parasite fauna of the Danubian barbel was studied in 1993-94 in the framework of a faunistic study. The objective of the study was to determine the relationship between changes in environmental factors and the prevalence and intensity of parasitic infections. This paper describes an epicellularly developing Goussia species from the barbel, and presents the histopathological characteristics of nodular coccidiosis found in the same fish species.

\section{MATERIALS AND METHODS}

Samples were taken regularly, at monthly intervals, between March 1993 and October 1994, always from 
the same place (Százhalombatta, a locality south of Budapest), and from the same fisherman who caught the fish on a contractual basis and stored them until their transfer to the laboratory. The fish weight varied from 275 to $1560 \mathrm{~g}$. First-summer barbel fry were occasionally seined from waters close to the bank. Some fish were frozen immediately after having been caught, and the content of their alimentary tract was examined in order to draw conclusions on the food structure of the Danubian barbel.

Fish were fasted in the fisherman's boat for $1 \mathrm{~d}$ after catching, to facilitate the parasitological examination of their intestinal tract, and transported to the laboratory alive. Scrapings taken from the mucosa and the transparent, mucous content of the evacuated gut were examined for the presence of unsporulated oocysts with an immersion lens, under a coverslip. Unsporulated oocysts were induced to sporulate in $400 \mathrm{ml}$ tap water at $25^{\circ} \mathrm{C}$ overnight, with intensive aeration and by the addition of crystalline penicillin (10000 IU) and streptomycin $(100 \mathrm{mg})$. The sporulated oocysts were examined by Nomarski's technique in an Olympus $\mathrm{BH}-2$ microscope. The parameters of 50 oocysts were recorded, and photographs were taken of the oocysts. For histological examination, the infected pieces of gut were fixed in Bouin's fixative, embedded in paraffin, cut into $5 \mu \mathrm{m}$ thick sections, and stained with haematoxylin and eosin.

\section{RESULTS}

By light microscopic examination of fresh preparations and by histological methods, developmental stages of 2 coccidia developing in different locations were detected in the mucosa of the first and second thirds of the gut of barbels aged 3 summers and more. First-summer barbel fry were not infected by either type of coccidiosis. Unsporulated oocysts of the epicellular species were present in large masses in the mucous gut content of fasted barbels. Unsporulated and partially sporulated oocysts of the other species, developing in supranuclear locations in the intestinal epithelial cells, were observed only in the epithelial cells of the gut. In the typical period of infection (from March to the beginning of June), the prevalence of the epicellular species was $18.4 \%$ (14/76), while the other coccidium species was found in a single fish only $(1 / 76$, $1.3 \%$ prevalence).

\section{Epicellular coccidiosis of barbel}

Stages of the epicellularly developing coccidium were found in the intestinal epithelial cells from the end of the first third throughout the entire second third of the gut. The gut mucosa was intact in the infected areas and did not differ macroscopically from that of infection-free fish. In the scrapings drawn off the mucosal surface and in the mucus found in the gut lumen, different developmental stages of a coccidium were observed. Besides a few cylindrical, slightly arcuate, apically slightly tapering merozoites which were 7.5 to $8 \mu \mathrm{m}$ long and $2 \mu \mathrm{m}$ wide, mostly young trophozoites, gamogonic stages and unsporulated oocysts (Fig. 1a) were present. The unsporulated oocysts were spherical or slightly oval, of highly refractile granular structure, 14 to $14.5 \mu \mathrm{m}$ in diameter, and bordered by a thin membrane. During sporulation in tap water at $25^{\circ} \mathrm{C}$ under aeration, the formation of sporozoites commenced (Fig. 1b), the oocyst membrane separated from the zygote undergoing quadripartition in the centre, and the length of the oocyst increased to between 17.5 and $18 \mu \mathrm{m}$ while its width almost remained unchanged. Final sporulation took place 24 to 36 h later when the oocysts reached their final size $(15.8-16.5 \times 12.8-13.5 \mu \mathrm{m})$, and the 4 sprocysts showing typical Goussia structure appeared in them (Fig. 1c, d). The sporozoites, like the merozoites observed in the mucosal scrapings, were of cylindrical shape and did not taper at their apical end. In the sporozoites a centrally located nucleus was easily discernible (Fig. 1d).

By histological examination, the different developmental stages of the coccidium were demonstrated in the apical part of the intestinal epithelial cells, in an epicytoplasmic position (Figs 2 to 6). Young trophozoites $(3.3$ to $5.8 \mu \mathrm{m})$ could be found in the brush

Figs. 1 to 6. Goussia koertingı n. sp. infecting Barbus barbus. Fig. 1. (a) Unsporulated zygote of Goussia koertingi ( $\times 1720$ ); (b) G. koertingi oocyst under sporulation $(\times 1690)_{i}$ (c) sporulated G. koertingi oocyst $(\times 1630)_{\text {i }}$ (d) strongly compressed G. koertingi oocyst $(\times 1630)$. Arrows: oocyst wall. Nomarski interference illumination. Fig. 2. Epicytoplasmatically developing $G$. koertingi trophozoltes (arrows) in the epithelium of the midgut of barbel. Ec: epithelial cells, L: lumen of the gut. Haematoxylin and eosin $(H \& E), \times 820$. Fig. 3. Epithelial cell (EC) layer compressed under the gamogonic developmental stages in a severely infected area of the intestinal epithelium. ma: macrogamonts, mi: microgamonts. H\&E, ×600. Fig. 4. G. koertingi trophozoites (arrows) developing in the brush border of epithelıal cells (Ec). R: rodlet cell, L: lumen of the gut. H\&E, $\times 950$. Fig. 5. Microgamonts (mi) and macrogamonts (ma) of G. koertingi. H\&E, $\times 600$. Inset: Trophozoite (t) located epicytoplasmatically in the intestinal epithelial cell (Ec). The empty arrow indicates the cell membrane of host cell origin bordering on the gut lumen. H\&E, $\times 1840$. Fig. 6 . Atrophy and nuclei pyknosis (arrows) of the epithelial cells beneath the macrogamonts and zygotes of G. koertingi. H\&E, $\times 600$ 


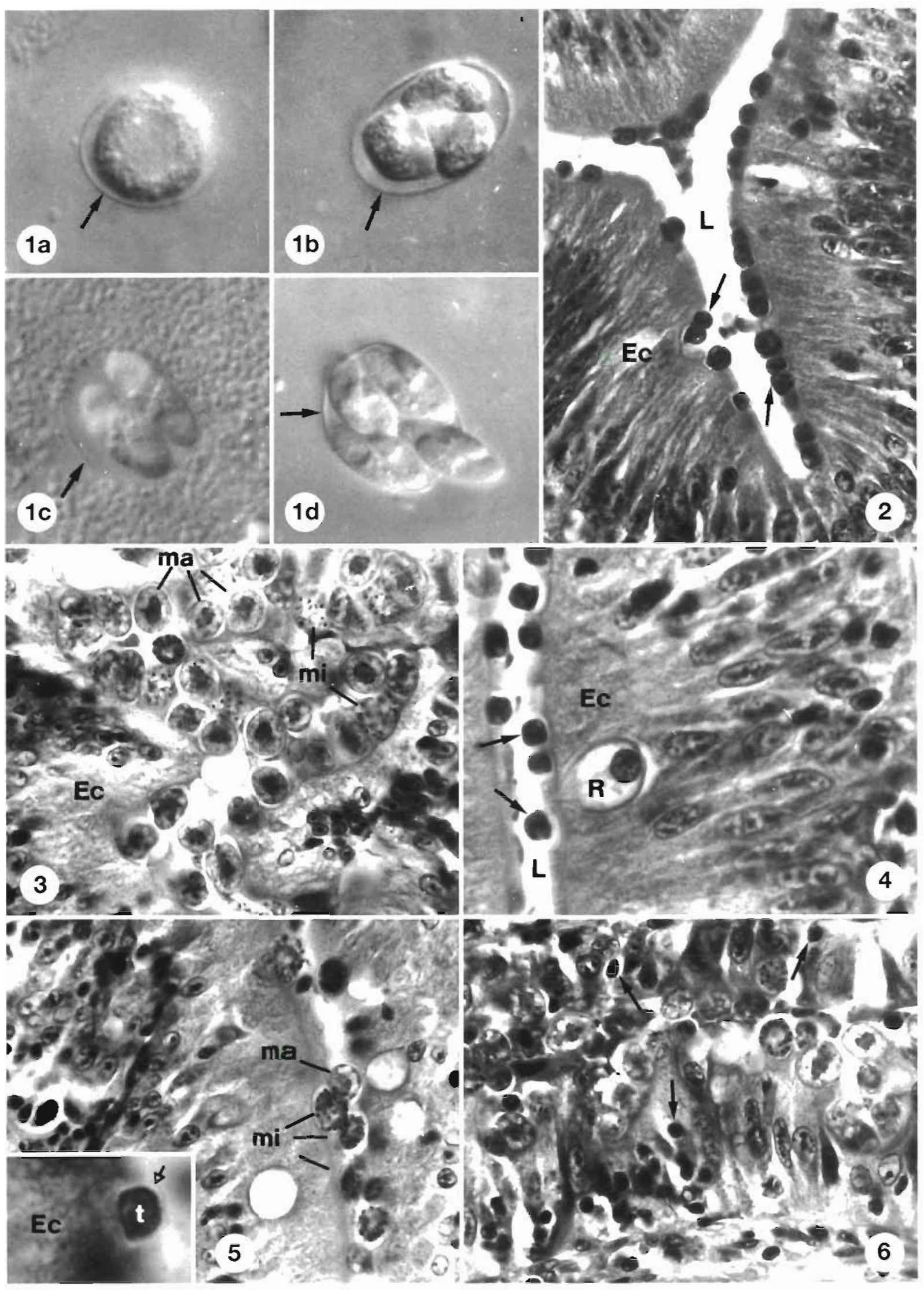




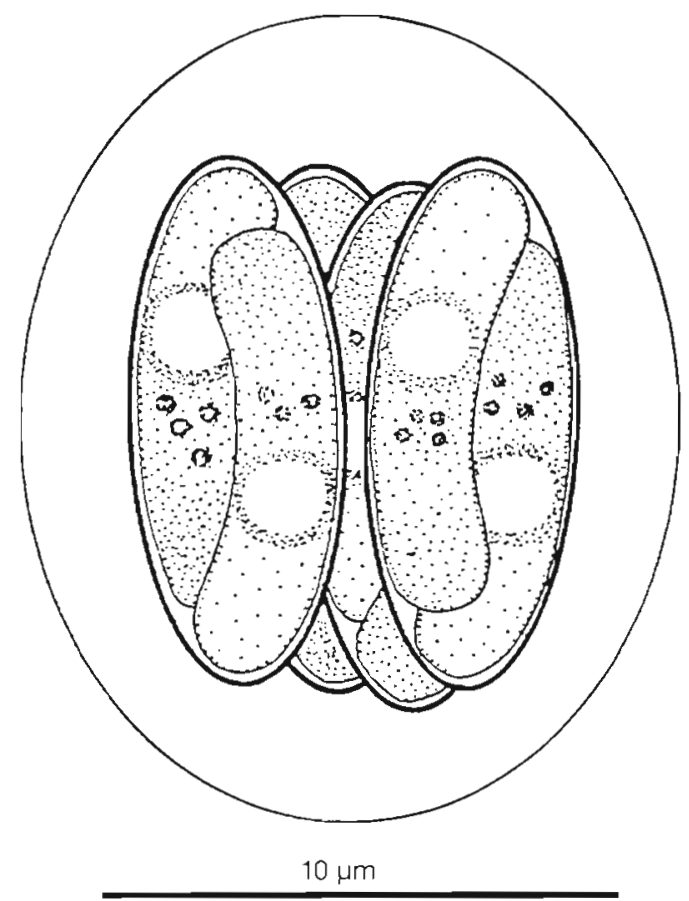

Fig. 7. Goussia koertingi n. sp. Line drawing of a sporulated oocyst

border of the intestinal epithelial cells throughout the entire length of the intestinal villi, from their tip down to their base. These stages, which were tightly packed and stained intensely with haematoxylin and eosin, occasionally caused a slight depression in the epithelial layer lying beneath them (Fig. 2). It was a conspicuous finding that in the most heavily infected areas the goblet cells, which are normally present in large numbers, were entirely absent from the intercellular spaces between intestinal epithelial cells. Of the gamogonic stages, the microgamonts measured 11 to $16 \mu \mathrm{m}$ and the macrogamonts 9.5 to $12 \mu \mathrm{m}$, and they developed mainly in the basal and middle third of the intestinal villi. In the microgamonts, the heads of several dozen microgametes, staining dark blue with haematoxylin, were seen in cross section, arranged at the periphery of the gamete. The cytoplasm of the macrogamonts stained pale with eosin, while the relatively Iarge, centrally located euchromatic nucleus stained blue with haematoxylin. The cytoplasm of the fertilised zygotes was of foamy structure, stained pale with eosin, and their nuclei were bluish-red. In areas severely infected with gamogonic stages, the epithelial cells under the gamonts had become markedly shorter (Figs. $3 \& 6$ ), their brush border had entirely disappeared, their cytoplasm showed pale staining with eosin, and some of the nuclei had become pyknotic (Fig. 6). So-called rodlet cells (Fig. 4) were often present in infected areas of the gut epithelium.
A description of the species on the basis of 50 sporulated oocysts follows.

Goussia koertingi n. sp.

Type host: Barbus barbus L.

Locality: Danube (Hungary).

Site of infection: Intestinal epithelium in the first and middle third of the gut, epicytoplasmic localization.

Prevalence of infection: $18.4 \%(14 / 76)$

Type material: Histological slides deposited in the protozoological collection of the Zoological Department, Hungarian Natural History Museum, Budapest. Coll. no.: PRC-96-1, PRC-96-2. Photo-negatives in the author's possession.

Oocysts (Figs. 1c \& 7) oval with a diameter of 16.0 $(15.8-16.5) \times 13.1(12.8-13.5) \mu \mathrm{m}$. Oocyst wall smooth, single-layered, very thin, colourless, transparent. Oocysts contain no micropyle, polar granule, or oocyst residuum. The 4 ellipsoidal sporocysts present in the oocyst contain 2 sporozoites each. Sporocysts lie parallel within the oocyst wall, and measure $10.6 \mu \mathrm{m}$ (10.5-11.0) in length and $4.3 \mu \mathrm{m}(4.1-4.5)$ in width. Sporocyst wall very thin and consists of 2 valves joined by a longitudinally running suture. Each sporocyst contains 2 slightly arcuate sporozoites arranged head to tail and blunt at both ends. After excystation, the sporozoites are banana shaped and measure $8.8 \mu \mathrm{m}$ $(8.6-9.0) \times 2.1 \mu \mathrm{m}(2.0-2.2)$. After sporulation for $48 \mathrm{~h}$, no compact sporocyst residuum was observed between the sporozoites; only 1 or 2 refractile granules were left behind within the sporocyst wall after sporulation had been completed.

Oocysts leave the fish in unsporulated state. The sporulation is exogenous.

Comments: In its location, Goussia koertingi n. sp. markedly differs from several Goussia and Epieimeria species described from fish. Based upon the taxonomical distance of the host species and the morphological structure of the oocysts, the Goussia species described in this paper is easily distinguishable from Goussia girellae isolated from the opaleye (Kent et al. 1988), $G$. trichogasteri described from the golden gourami (Székely \& Molnár 1992), Epieimeria anguillae Leger et Hollande, 1922 reported from the eel, and Goussia acipenseris detected in the sterlet (Molnár 1986). Goussia koertingi n. sp. is morphologically different from the likewise epicellularly developing G. pannonica (Molnâr 1989) described from Danubian and Lake Balaton white bream Blicca bjoerkna, as the sporocysts of the latter species always contain a sporocyst residuum and the shape of their sporozoites is also different. Goussia koertingi n. sp. shows the closest resemblance to G.janae (Lukes \& Dykova 1990), a coccidium which occurs in epicellular locations in European fish belonging to the Leuciscus genus. However, the new 
species described from the barbel has smaller oocysts and sporocysts, and its oocysts have a characteristically ellipsoidal shape. An especially important difference can be observed at the apical end of the sporozoites. While the sporozoites of the species described by Lukes \& Dykova (1990) taper at their apical end, the corresponding developmental stages of the coccidian reported from the barbel have a rounded apical end. Goussia koertingi n. sp. can be distinguished from $G$. pigra, a coccidium also developing in epicellular locations in another cyprinid fish (Scardinius erythrophthalmus), by sporozoite shape, sporocyst structure, and oocyst size $(16 \times 13 \mu \mathrm{m}$ for $G$. koertingi vs $17-19 \times$ $14 \mu \mathrm{m}$ for $G$. pigra).

The parasite has been named in honour of Professor W. Körting, a renowned specialist of fish-parasitic protozod.

\section{Nodular coccidiosis of barbel}

This infection was diagnosed in a single fish specimen only, and was studied exclusively on the basis of the histological findings; the sporulated developmental stages of the coccidium in fresh preparations were not studied.

In the gut, especially in the middle third of the intestine, the presence of grayish-white nodules in the gut wall, easily visible even from the serosal side, was already apparent at dissection. When examined from the mucosal side, the nodules measured 2 to $5 \mathrm{~mm}$ in diameter and were also of grayish-white colour. In cross sections of the gut wall, discolouration of the gut wall in the entire thickness of the mucosa down to the muscular layer was seen under the superficially located nodule. In the gut lumen there was a yellowish-green, transparent, jelly-like content. By microscopic examination this was found to contain large numbers of Spironucleus protozoa, eggs of the parasite Pomphorhynchus laevis (Acanthocephala), and so-called yellow bodies.

In histological preparations examined under low magnification, circumscribed degeneration of the gut wall and disintegration of its tissue structure were observed. Nodules were seen embedded in areas containing intact intestinal folds (Fig. 8). Using a higher magnification, the structure of both the healthy and the infected intestinal villi could be examined easily at the border of intact and infected areas (Fig. 9). Intact intestinal folds were spherical in cross section: the epithelial cells bordered by a brush border surrounded the narrow or only slightly dilated lumen in a regular circle. Goblet cells containing large amounts of mucus in their apical part were located among the epithelial cells (Fig. 9). Infected intestinal folds were irregular in cross section, the intestinal epithelial cells had an indistinct structure, and the gut lumen was markedly dilated. No merogonic stages were seen. No intact epithelial cells or goblet cells were seen among the large numbers of gamogonic and sporogonic stages developing in the enterocytes (Figs. 10 \& 11). Some oocysts had already started to sporulate in the tissues (Fig. 10). A parasitophorous vacuole could be observed only around macrogamonts showing advanced development and presporogonic stages; younger macrogamonts and microgamonts completely filled the lumen of the parasitophorous vacuole. It was a typical pathological finding that the epithelial cells of the infected intestinal villi lost their characteristic structure on their luminal surface: the brush border completely disappeared (Figs. $10 \& 11$ ).

\section{DISCUSSION}

Until this study, no coccidium species causing either epicellular or nodular coccidiosis had been identified from the barbel, although Molnár (1989) found unsporulated oocysts in Danubian barbels in April. However, he classified their type of development as 'mucosal', and the morphological characteristics of the oocysts sporulated by him (Goussia sp. IV) differ from those of Goussia koertingi n. sp. described in this paper. In the same paper, Molnár (1989) also mentioned epicellularly developing species from other cyprinids (Goussia sp. VII, Goussia sp. VIII, Goussia sp. IX, Goussia sp. X), but did not describe them as new species; rather, he only provided data characteristic of oocyst morphology. Based upon its oocyst dimensions, the species found in Leuciscus cephalus and designated Goussia sp. IX is probably identical with $G$. janae, a similarly epicellular species subsequently described by Lukes \& Dykova (1990). The possibility cannot be excluded that the remaining 3 coccidia designated by numbers only are also valid Goussia species of their hosts, which resemble each other only in their size and type of development; however, whether or not this is so can be elucidated only by the re-isolation and detailed description of these species.

The type of development of fish coccidia characterised by epicytoplasmic development of different stages in the brush border of epithelial cells was first elucidated electron microscopically by Molnár \& Baska (1986), using the example of Epieimeria anguillae Leger et Hollande, 1922 infection of eel. They pointed out that, in contrast to earlier assumptions reported in the literature, this coccidium also forms its merogonic and gamogonic stages epicytoplasmatically, within a parasitophorous vacuole, while (following shrinkage of 


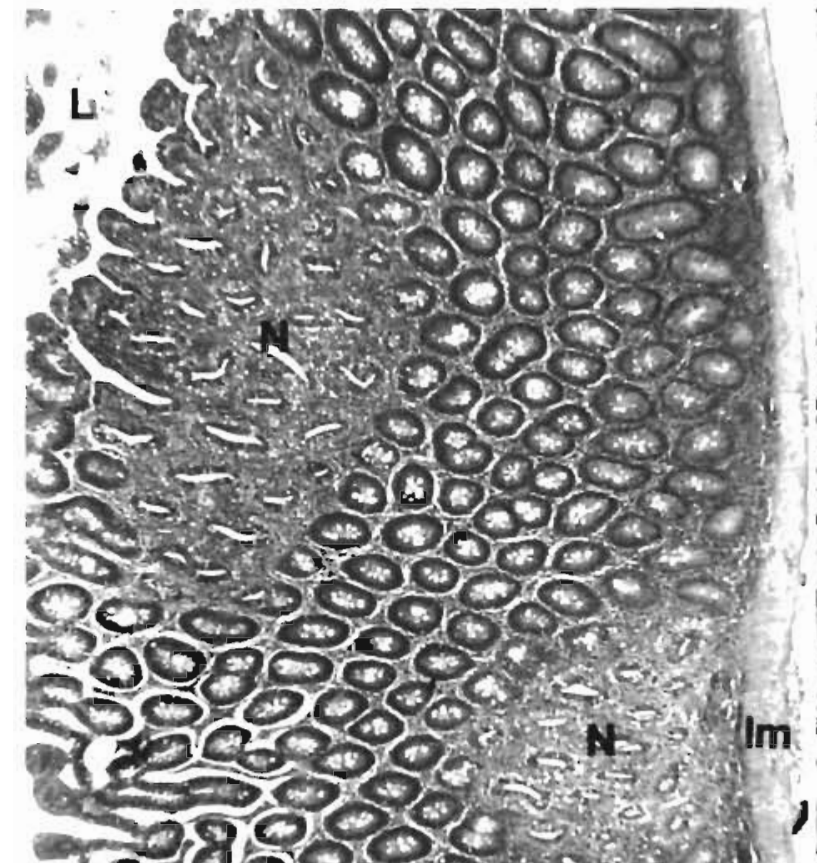

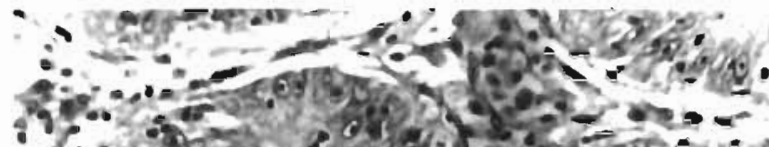

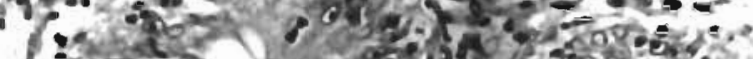

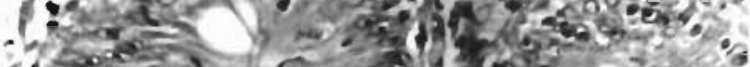

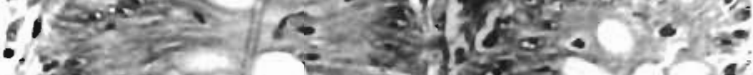

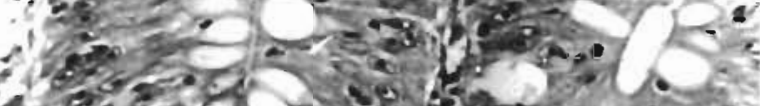

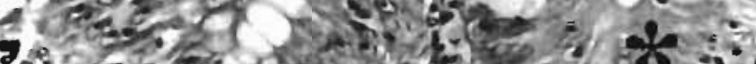

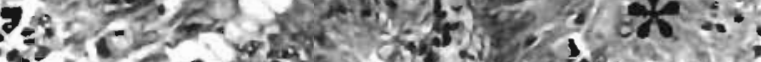

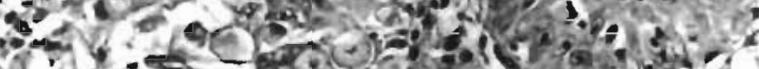
(1) $2-5-$ an.

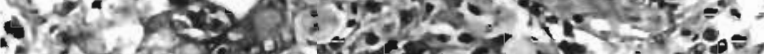
10.460 .

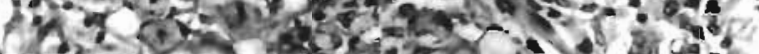

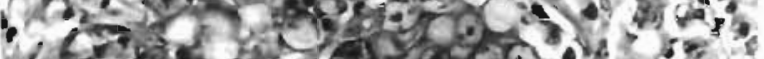

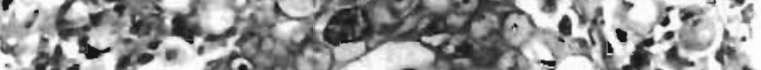

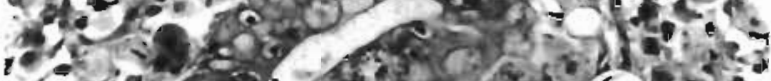

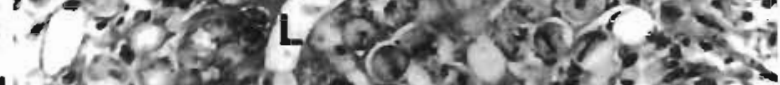

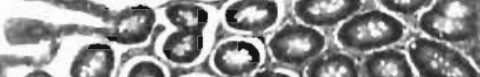

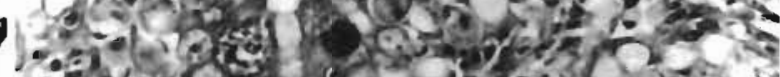

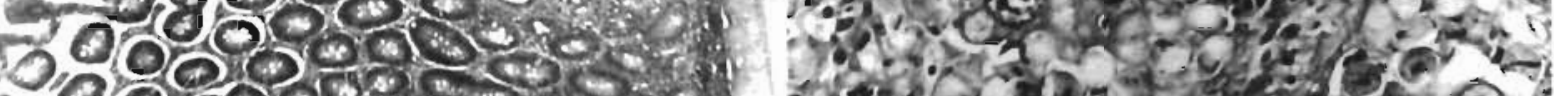

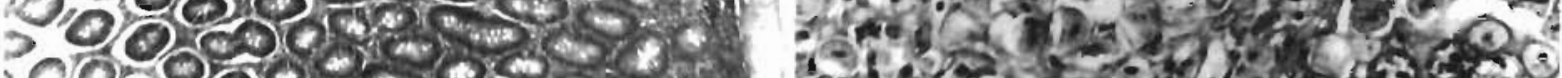

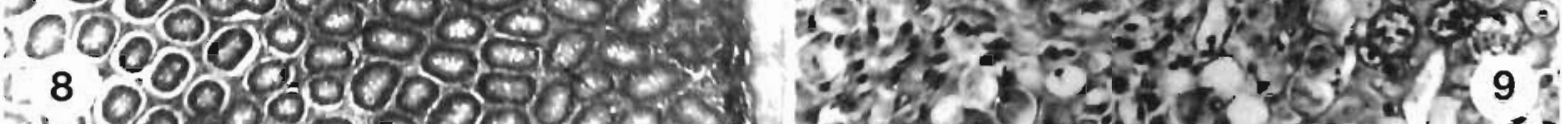

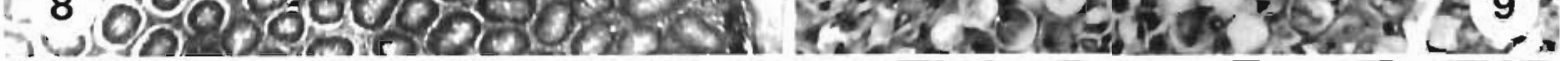

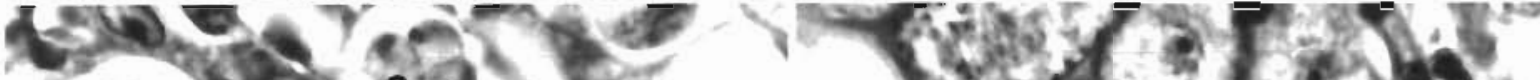

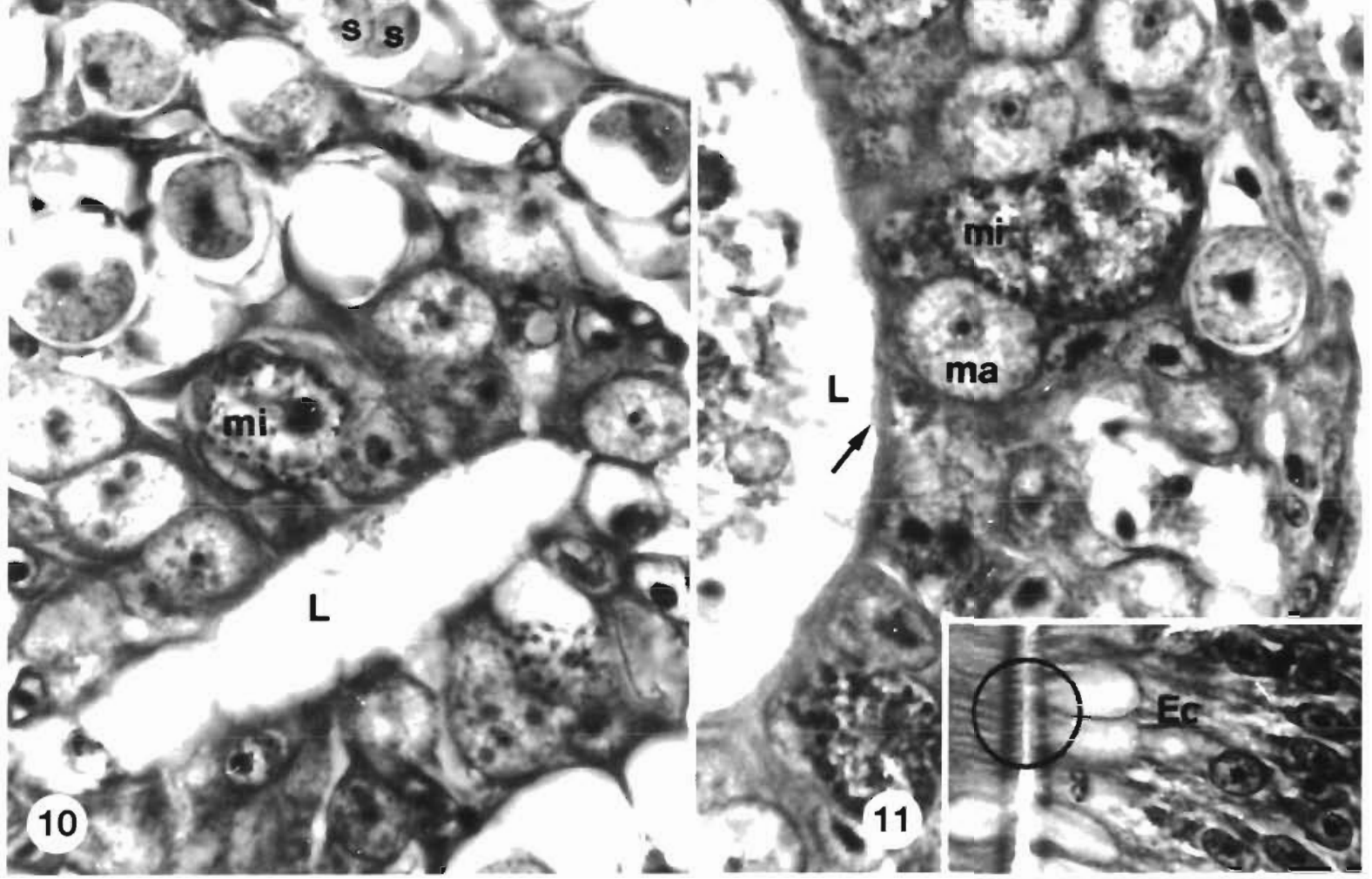


Figs. 8 to 11 Unidentified coccidium infecting Barbus barbus. Fig. 8. Low-magnification view of nodular coccidiosis in barbel. The 2 nodules, the light areas $(N)$, are located between the intact intestinal villi. Im: lamina musculosa, L: lumen of the gut. H\&E, $\times 35$. Fig. 9. Cross section of an intact intestinal villus $(\boldsymbol{*})$ and a villus severely infected by developmental stages of coccidia. L: crypt lumen of the infected intestinal villus. H\&E, $\times 330$. Fig. 10 . Cross section of an intestinal villus infected by gamogonic stages of coccidia. L: lumen, mi: microgamont, s: forming sporocysts of a sporulating oocyst. H\&E, $\times 1100$. Fig. 11 . Sector of intestinal epithelial cells infected by gamogonic stages, with an eroded brush border The cells are covered only by a thin eosinophilic layer (arrow). ma: macrogamont, mi: microgamont, L. crypt lumen. H\&E, $\times 1350$. Inset: intact brush border of control, uninfected intestinal epithelial cells (Ec) (inside the circle). H\&E, $\times 1440$

the infected host cell) its sporogonic stages may find their way among the epithelial cells and can be detected there by histological examination. The trophozoites and gamogonic stages of Goussia koertingi n. sp. described here were also located epicytoplasmatically. The infected epithelial cells were often pressed towards the basal membrane, taking with them the yet unreleased zygotes awaiting sporulation. Examination of fresh and histological preparations has failed to furnish evidence that this species causes substantial tissue damage and disease in barbels.

From the species Barbus capito conocephalus, Davronov (1987) reported a new species, named Eimeria barbi. The oocysts of that species bore typical Eimeria characters: the 4 sporocysts had a stieda-like knob. The average length and width of E. barbi oocysts was $23.6 \mu \mathrm{m}$ and $20.5 \mu \mathrm{m}$, respectively. The same paper mentions the occurrence in Barbus capito conocephalus of an Isospora $\mathrm{sp}$. which has a spherical oocyst $11.9 \times 20.4 \mu \mathrm{m}$ in size. As Davronov (1987) failed to give data on the development of these species in the tissues, the type of their development cannot be determined; however, their identity with the species Goussia koertingi n. sp. can easily be ruled out on the basis of morphometrical characteristics. Davronov (1987) isolated all coccidia mentioned in his paper by a flotation procedure of faecal samples; in doing so, he disregarded Molnár's (1977) methodological finding that flotation in concentrated saline solution is unsuitable for the collection of fish coccidia due to the fragility of their oocyst wall. The oocysts recovered from fish faeces by that method are usually avian or mammalian coccidia ingested by the fish with the feed, as these coccidia have a more resistant oocyst wall. In view of this fact, the intrapiscine development of the coccidium species described in Davronov's (1987) paper can be excluded. Similar errors have repeatedly resulted in the description of new species; therefore, in the present author's opinion, new species of coccidia cannot be described on the basis of oocyst-sporocyst morphometry alone, without providing data on the endogenous development. Based upon these facts, the species described by Davronov (1987) should be regarded as nomen nudum.
Besides differing in morphological characteristics, the species found in barbel by the present author also markedly differ from Goussia carpelli causing diffuse coccidiosis in common carp and crucian carp in the type and seasonality of development in the intestinal epithelial cells. While G. carpelli develops in several cycles each year (Zmerzlaya 1966), the barbel parasites described in this paper are characterised by a 1 yr cycle of development. Although Shulman (1984) and Alvarez-Pellitero \& Gonzalez-Lanza (1986a) mention the occurrence of $G$. carpelli in barbel and in an Iberian subspecies thereof, the narrow host specificity of coccidia renders it unlikely that this species could develop in the barbel. This is supported by the findings of Lukes et al. (1991), who established by crossinfection experiments with $G$. carpelli in several cyprinid fish species that only the common carp and the crucian carp could be infected successfully.

Based upon the histological examinations, it can be established with high probability (even in the absence of sporulated oocysts derived from a nodule) that the coccidian stages simultaneously found in the barbel in 2 different locations of development belong to 2 different species. This is supported by the finding that the majority of infected fish were infected by 1 of the 2 species only (the epicellular one). In addition, Molnár (1986, 1989) furnished evidence that in the sterlet and in cyprinids an epicytoplasmatically developing coccidium species and a coccidian of supranuclear location may be present in the intestinal epithelium simultaneously.

The nodular coccidiosis observed in barbel by the present author resembles the lesions caused by Goussia subepithelialis in the common carp (Moroff \& Fiebiger 1905, Schäperclaus 1943, 1954, Marincek 1973), but it also bears resemblance to the nodular coccidiosis described in tench and white bream (Molnár 1982, 1989) as well as in pikeperch (Molnár 1996) in that the stages of the coccidium develop in circumscribed areas of the gut epithelium, and all species develop according to a 1 yr cycle. The tissue changes occurring in the gut bear a closer resemblance to the lesions caused by G. subepithelialis in common carp than to the direct expulsion observed by Molnár (1982) in tench. To explain the difference observed between 
the infection of common carp and that of tench, Lom \& Dykova (1992) suggested that tench is not a natural host for G. subepithelialis; thus, the difference can be attributed to the different cellular reaction of the fish host rather than to that of the coccidium. In the coccidial infection found in the barbel, the majority of unsporulated oocysts are probably expelled into the gut Iumen.

Although the studies reported here did not reveal lesions of pathological importance, the possibility cannot be ruled out that coccidia may acquire increased pathogenicity in fish species reared in intensive culture. Such increased pathogenicity was reported by Molnár (1976) for Eimeria sinensis Chen, 1956, a coccidium parasitizing silver carp and bighead. Similarly, the pathological role of coccidia was emphasized by Dykova \& Lom (1981) in their paper on the life cycles, classification and pathogenicity of these parasites. They stated that, besides diffuse coccidiosis, nodular coccidiosis may also play a role in causing disease in the common carp. Based upon the findings of this study, in barbel the nodular form seems to have greater pathological importance, but not from the epidemiological point of view, as the prevalence of infection was low while its intensity high. At the same time, both types of coccidiosis may contribute to the aggravation of Spironucleus infection frequently occurring in the barbel, through their damaging effect exerted on the epithelial cells involved in the local defence mechanisms. Spironucleosis is an important disease of the barbel: Molnár (1966) pointed out that concurrent helminth Pomphorhynchus laevis infections predispose the barbel to the generalized form of spironucleosis which leads to emaciation and death of the host fish.

Acknowledgements. The author thanks Dr Kálmán Molnár for his advice and comments, and especially Mrs Éva Zsély for the histological support. The research presented in this paper was supported by grant no. GZ 45.313/2-IV/6a/93 of the Bundesministerium für Wissenschaft und Forschung, Austria, and by the National Research Fund of Hungary (OTKA), project no. T014648.

\section{LITERATURE CITED}

Alvarez-Pellitero MP. Gonzalez-Lanza MC (1986a) Goussia carpelli (Protozoa: Apicomplexa) in cyprinid fish of the Duero Basin (NW Spain). Aspects of host-parasite relationships. J Appl Ichthyol 3:125-130

Alvarez-Pellitero MP, Gonzalez-Lanza MC (1986b) Eimeria spp. from cyprinid fish of the Duero basin (north-west Spain). J Fish Dis 9:325-336

Davronov O (1987) Fish coccidia in Uzbekhistan. Parazitologiya 21:115-120 (in Russian)

Dykova I, Lom J (1981) Fish coccidia: critical notes on life cycles, classification and pathogenicity. $J$ Fish Dis 4 : $487-505$

Responsible Subject Editor: W. Körting, Hannover, Germany
Ergens R, Gussev AV, Izyumova NA, Molnár K (1975) Parasite fauna of fishes of the Tisa River basin. Praha Academia, Prague

Kent LM, Fournie JW, Snodgrass RE, Elston RA (1988) Goussia girellae n. sp. (Apicomplexa: Eimeriorina) in the opaleye, Girella nigricans. J Protozool 35:287-290

Lom J, Dykova I (1992) Protozoan parasites of fishes. Development in Aquaculture and Fisheries Science, 26. Elsevier, Amsterdam

Lukes J, Dykova I (1990) Goussia janaen. sp. (Apicomplexa: Eimeriorina) in dace Leuciscus leuciscus and chubb $L$. cephalus. Dis Aquat Org 8:85-90

Lukes J, Steinhagen D, Körting W (1991) Goussia carpell (Apicomplexa, Eimeriorina) from cyprinid fish: field observations and infection experiments. Angew Parasitol 32: $149-153$

Marincek M (1973) Development d'Eimeria subepithelialis (Sporozoa, Coccidia) parasite de la carpe. Acta Protozool 19:197-215

Molnár K (1966) On the emaciation of the barbel in the River Danube. Halászat 16:42-43 (in Hungarian)

Molnár K (1976) Histological study of coccidiosis caused in the silver carp and the bighead by Eimeria sinensis Chen, 1956. Acta Vet Hung 26:303-312

Molnar K (1977) Comments on the nature and methods of collection of fish coccidia. Parasitol Hung 10:41-45

Molnár K (1982) Nodular coccidiosis in the gut of the tench Tinca tinca L. J Fish Dis 5:461-470

Molnár K (1986) Occurrence of two new Goussia species in the intestine of the sterlet Acipenser ruthenus. Acta Vet Hung 34:169-174

Molnár K (1989) Nodular and epicellular coccidiosis in the intestine of cyprinid fishes. Dis Aquat Org $7: 1-12$

Molnár K (1996) Nodular coccidiosis of the pikeperch Stizostedion lucioperca and Volga perch Stizostedion volgensis. Dis Aquat Org 27:35-41

Molnár K, Baska F (1986) Light and electron microscopic studies on Epieimeria anguillae (Leger et Hollande, 1922), a coccidium parasitizing the European eel, Anguilla anguilla L. J Fish Dis 9:99-110

Moroff T, Fiebiger J (1905) Über Eimeria subepithelialis n. sp. Arch Protistenkd 6:166-174

Reichenbach-Klinke HH (1962) Die Parasiten der Donaufische. Arch Hydrobiol Suppl 27:40-56

Schäperclaus W (1943) Die Darmcoccidiosen, insbesondere die Knötchencoccidiose des Karpfens. Z Fischerei 41. 283-295

Schäperclaus W (1954) Fischkrankheiten. Akademie Verlag, Berlin

Shulman SS (1984) Sporozoa Leuckart, 1872, emend. Krylov, Dobrovolsky, 1980. In: Bauer ON (ed) Key to the parasites of freshwater fauna of USSR. 1. Nauka, Leningrad, $p 48-72$

Székely Cs, Molnár K (1992) Coussıa trichogasteri n. sp. (Apicomplexa: Eimeriidae) infecting the aquarium-cultured golden gourami Trichogaster trichopterus trichopterus. Dis Aquat Org 13:79-81.

Zitnan R (1965) Results of research on endohelminths parasitizing fish of the Latorca River. Sborn Vychodoslov Muzea, Ser B, 6:35-44 (in Slovakiar)

Zitnan R (1968) Helminthofauna of fish living in Czechoslovakian reaches of the River Tisza. Sborn Vychodoslov Muzea, Ser B, 9:83-89 (in Slovakıan)

Zmerzlaya EI (1966) Temperature effect upon the infestation of carps with coccldia Eimeria carpelli Leger et Stankovitsch, 1921. Zool Zh 45:305-307

Manuscript first received: June 11, 1996

Revised version accepted: January 20, 1997 